\title{
Self-Assembled Nanoparticles of Diruthenium(II,III)-Ibuprofen Anticancer Metallodrug
}

\author{
Hanif-Ur-Rehman, ${ }^{a}$ Marcio Hayashi, ${ }^{a}$ Samara R. Alves, ${ }^{a}$ Iguatina M. Costa $^{a}$ and \\ Denise de Oliveira Silva ${ }^{(*, a}$

\begin{abstract}
${ }^{a}$ Laboratório de Química Inorgânica Sintética e Estrutural - Bioinorgânica e Metalofármacos, Departamento de Química Fundamental, Instituto de Química, Universidade de São Paulo, Av. Prof Lineu Prestes, 748, 05508-000 São Paulo-SP, Brazil
\end{abstract}

\begin{abstract}
The diruthenium(II,III)-ibuprofen (RuIbp) metallodrug shows anticancer activity in vitro and in vivo. The encapsulation into lipid nanoparticles enhanced the efficacy in glioblastoma, breast and prostate cancer cells. Here we report data for RuIbp hydrophobicity, solubility in alcohol/ water, and behavior in 1-5\% ethanol/water and ethanol/cell culture medium. RuIbp is capable of spontaneously generate self-assembled RuIbpNP nanoparticles when drug ethanolic solutions are added to water or cell growth culture medium at $1-5 \%$ ethanol. The phenomenon was investigated, and the nanoparticles characterized. RuIbpNP nanoparticles formed at 100-200 $\mu \mathrm{mol} \mathrm{L}^{-1} \mathrm{RuIbp}$ are colloidally stable and nearly spherical showing zeta potential about $+40 \mathrm{mV}$ and particle size about 100 (aqueous suspension) and $180 \mathrm{~nm}$ (culture medium). The integrity of the $\left[\mathrm{Ru}_{2}(\mathrm{Ibp})_{4}\right]$ framework was confirmed by spectroscopy and mass spectrometry. Significant amount of metallodrug was found in suspension ( $85 \%$, culture medium; $54 \%$, culture medium with cells). The uptake by U87MG glioblastoma cells was $6 \%$ at $24 \mathrm{~h}$. The spontaneous nanosizing of RuIbp in the form of nanosuspensions may explain the biological activity of this highly hydrophobic metallodrug. The present findings expand the knowledge on the behavior of Rulbp, opening new directions to exploit the properties of the metallodrug targeting cancer therapy.
\end{abstract}

Keywords: diruthenium, ibuprofen, anticancer metallodrug, self-assembled nanoparticles

\section{Introduction}

Cancer is at the top of diseases which cause death all over the world, thus requiring multiple approaches in therapy. The well stablished efficacy of platinum-based chemotherapy together with the clinic drawbacks has motivated the study of non-platinum, including ruthenium, based drugs in the past years. ${ }^{1}$ The promising biological properties of a variety of ruthenium compounds, ranging from classic coordination complexes to organometallics, ${ }^{2-13}$ placed the metal at the spotlight at metal-based anticancer drugs research. However, this field faces challenges such as the low stability tending to favor undesirable reactions of metal compounds in the biological environment. The approach of developing metal-based drug nanocarriers, nowadays comprising from supramolecular coordination complexes ${ }^{14}$ to nanostructured materials, ${ }^{15,16}$ aiming future biomedical applications, besides all the known benefits and

*e-mail: deosilva@iq.usp.br

Dedicated to Prof Henrique Eisi Toma on the occasion of his $70^{\text {th }}$ birthday. the enhanced permeability and retention (EPR) effect, ${ }^{17}$ may show the advantage of promoting stabilization to avoid metal coordination sphere degradation. However, since undesirable reactions may result in structural changes during the drug loading process, the construction of metallodrug carriers requires rational design, well-controlled synthesis and drug-loaded carrier reliable characterization. ${ }^{18,19}$ The investigation of carrier systems for delivering platinum drugs to tumor sites led a cisplatin liposomal formulation (Lipoplatin ${ }^{\circledR}$ ) to phase III clinical trials. ${ }^{14,15,20}$ The development of carrier systems for ruthenium metallodrugs has also received attention. ${ }^{15,21-24}$ Nanoparticle polymeric systems developed for $\mathrm{Ru}^{\mathrm{III}}$ drugs which reached clinical trials (i.e., the cytotoxic $\mathrm{KP} 1019$ ( $\mathrm{Hind}\left[\mathrm{RuCl}_{4}(\mathrm{ind})_{2}\right]$; ind, $1-H$-indazole) and the anti-metastatic NAMI-A ((Him) $\left[\mathrm{RuCl}_{4}(\mathrm{dmso})(\mathrm{im})\right]$; im, 1- $H$-imidazole $\left.)\right)$ showed enhanced activity compared with the free drugs. ${ }^{25,26}$

It is also known that features such as solubility, bioavailability and dissolution rate, which affect biological efficacy of water poorly soluble drugs in general, may be overcame by nanosizing the drugs directly 
as nanosuspensions, nanoparticles or nanocrystals. Nanosuspensions (colloidal dispersions) of the drugs, besides overcoming poor solubility and bioavailability, may also modify the pharmacokinetic profiles and thus improve safety and efficacy of drugs. ${ }^{27}$

Our research group has worked on the development of a unique class of diruthenium-based drugs bearing carboxylate bioactive ligands such as non-steroidal anti-inflammatory drugs (NSAIDs). ${ }^{2,12}$ In these metallodrugs, a metal-metal multiply bonded $\mathrm{Ru}_{2}{ }^{\mathrm{II}, \mathrm{III}}$ mixed-valence core coordinated to four carboxylate drug ligands is arranged in a $\left[\mathrm{Ru}_{2}\left(\mathrm{O}_{2} \mathrm{CR}\right)_{4}\right]$ paddlewheel type geometry. This combination promotes synergistic effects which enhance the anticancer activity in relation to the clinically used parent NSAIDs. ${ }^{28-34}$ The metallodrug of ibuprofen (HIbp), the $\left[\mathrm{Ru}_{2}(\mathrm{Ibp})_{4} \mathrm{Cl}\right]$ (or RuIbp, in which Ibp is carboxylate anion from ibuprofen), shown in Figure 1, exhibits promising results against the aggressive, highly resistant glioblastoma (GBM) brain malignant primary tumor. The RuIbp inhibited C6 rat glioma cell proliferation in vitro, ${ }^{28}$ was capable of decreasing the tumor area in C6 rat orthotopic glioma in vivo without showing significant toxicity, ${ }^{32}$ and inhibited the cell proliferation in human glioma cell lines showing the effects of increasing apoptotic while decreasing mitotic cell numbers, besides inhibiting cell migration. ${ }^{34}$ The mechanism of action is still unknown, but it might involve activation by ligand substitution ${ }^{35}$ and/or oxidation-reduction ${ }^{36}$ reactions. Furthermore, multiple biological targets, comprising relevant biomolecules, ${ }^{37,38}$ proteins of the cell cycle, ${ }^{29}$ and the cyclooxygenase isoforms, ${ }^{29,31}$ might be associated to the metallodrug activity. The encapsulation of RuIbp into intravenous administrable biocompatible lipid nanoparticles promoted enhanced efficacy and increased cellular uptake in vitro, in the U87MG and the T98G cisplatin chemoresistant human glioblastoma cells (RuIbp-loaded terpolymer-lipid nanoparticles; RuIbp-TPLNs), ${ }^{19}$ and in breast and prostate human cancer cells (RuIbp-loaded solid-lipid nanoparticles; RuIbp-SPLNs). ${ }^{18}$ Since this metallodrug is poorly soluble in water, the effect of nanoencapsulation might be in part associated to overcoming the low solubility. All these findings, however, could not explain the biological performance of this metallodrug if its poor aqueous solubility is taken into account. In similar way to the majority of aqueous low solubility drugs, the biological assays were based on adding a small volume of stock organic solution of the metallodrug to a much higher volume. In this work, we describe recent findings which may contribute to elucidate the behavior of RuIbp when the metallodrug stock solution in ethanol is added to the aqueous growth culture medium. The hydrophobicity (partition coefficient in octanol/water), the solubility in organic solvent/water mixed solvents, and behavior of the compound in 1-5\% ethanol/water and 1-5\% ethanol/cell growth medium are reported.

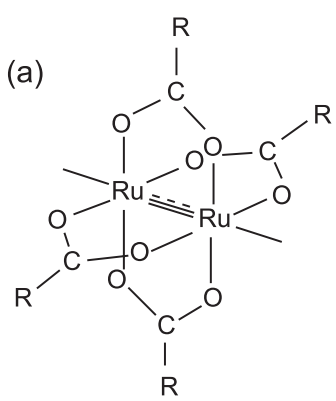

(b)

Figure 1. The paddlewheel dimetallic structure of the $\left[\mathrm{Ru}_{2}(\mathrm{Ibp})_{4}\right]$ framework (a) where RCOO represents the ibuprofenate anion from the HIbp ibuprofen drug (b).

\section{Experimental}

\section{Materials}

All chemicals were purchased from Sigma-Aldrich (São Paulo, Brazil). Ethanol (EtOH), methanol (MeOH), propanol $(\mathrm{PrOH})$, other solvents and the acids (hydrochloric acid $(\mathrm{HCl})$, sulfuric acid $\left(\mathrm{H}_{2} \mathrm{SO}_{4}\right)$ and acetic acid (HAc)) were from Merck (São Paulo, Brazil) or Lab-Synth (São Paulo, Brazil). The ibuprofen (HIbp) drug was from manipulation Natural Pharma Pharmacy (São Paulo, Brazil). The $\left[\mathrm{Ru}_{2}(\mathrm{Ibp})_{4} \mathrm{Cl}\right]$ was synthesized from the $\left[\mathrm{Ru}_{2}\left(\mathrm{O}_{2} \mathrm{CCH}_{3}\right)_{4} \mathrm{Cl}\right]$ precursor according to the previously described procedure. ${ }^{34}$ Water in all experiments was distilled deionized (DDI).

\section{Determination of the partition coefficient of Rulbp}

The partition coefficient $(\log \mathrm{P})$ was determined by the shake flask method. Solutions of the drugs were prepared in $n$-octanol and kept under stirring. The systems were pre-saturated. Then, the octanolic solution was added to water and stirred in an incubator at $120 \mathrm{rpm}$ for $60 \mathrm{~min}$, at $25{ }^{\circ} \mathrm{C}$. After that, aliquots of the aqueous and the octanolic phases were analyzed by electronic absorption spectroscopy. The determination of the amount of drug in each phase was based on calibration curves previously built for both ibuprofen (water or methanol, at $221 \mathrm{~nm}$ ) and RuIbp (methanol or ethanol at 221 and $428 \mathrm{~nm}$; propanol, at 221 and $444 \mathrm{~nm}$ ).

\section{Solubility of Rulbp in alcohol/water mixed solvent}

This experiment was performed at $25{ }^{\circ} \mathrm{C}$ for the alcohol/water mixed solvents: methanol/water, ethanol/ water and propanol/water. For each case, a series of mixtures was prepared by adding determined mass (x) 
of the organic solvent to a determined mass $(20-x)$ of water to reach $20 \mathrm{~g}$ final mass, according to the following solvent:water $(\mathrm{m} / \mathrm{m})$ ratios: 10:0, 9:1, 8:2, 7:3, 6:4, 5:5, 4:6, 3:7, 2:8, 1:9 and 0:10. Then, the RuIbp solid compound (weighted mass) was added to volumes of 1.0 to $3.0 \mathrm{~mL}$ of these mixtures and the flasks hermetically sealed were kept under stirring at $150 \mathrm{rpm}$ for $24 \mathrm{~h}$. The amount of dissolved metallodrug, after dilution in the selected solvent, was determined by electronic absorption spectroscopy with the basis on calibration curves previously built for RuIbp (methanol or ethanol at 221 and $428 \mathrm{~nm}$; propanol, at 221 and $444 \mathrm{~nm}$ ).

\section{Behavior of Rulbp in 1-5\% ethanol/water}

In the first experiment, distinct volumes of $10 \mathrm{mmol} \mathrm{L}^{-1}$ freshly prepared ethanolic solution of RuIbp $(10 ; 20 ; 30 ; 40$; $50 \mu \mathrm{L}$ ) were added to water $(990 ; 980 ; 970 ; 960 ; 950 \mu \mathrm{L}$, respectively) to achieve final concentrations of metallodrug at about 100; 200; 300; 400; $500 \mu \mathrm{mol} \mathrm{L}^{-1}$, respectively, and $1 ; 2 ; 3 ; 4 ; 5 \%$ ethanol $(\mathrm{v} / \mathrm{v})$, respectively. In the following experiments, the procedure was conducted for concentrations of metallodrug separately fixed at 100 and $200 \mu \mathrm{mol} \mathrm{L}{ }^{-1}$, while EtOH percentage was varied $(1 ; 2 ; 3$; $4 ; 5 \%(\mathrm{v} / \mathrm{v}))$. The suspensions were stirred for $1-2 \mathrm{~min}$ in a VELP magnetic multistirrer.

\section{Behavior of Rulbp in 1-5\% ethanol/water containing acid}

\section{Experiment 1 with hydrochloric acid}

(i) $80 \mu \mathrm{L}$ volumes from $10 \mathrm{mmol} \mathrm{L} \mathrm{L}^{-1}$ RuIbp fresh ethanolic solution were separately added to Falcon tubes containing water $(3920 ; 3880 ; 3840 ; 3800 ; 3760 \mu \mathrm{L})$ and $10 \mathrm{mmol} \mathrm{L}{ }^{-1} \mathrm{HCl}(0 ; 40 ; 80 ; 120 ; 160 \mu \mathrm{L}$, respectively), to give final $200 \mu \mathrm{mol} \mathrm{L}{ }^{-1}$ RuIbp and 0; 100; 200; 300; $400 \mu \mathrm{mol} \mathrm{L}{ }^{-1} \mathrm{HCl}$, respectively; (ii) the procedure was repeated by using $80 \mu \mathrm{L}$ from $5 \mathrm{mmol} \mathrm{L}^{-1}$ RuIbp ethanolic solution, water $(3920 ; 3900 ; 3880 ; 3860 ; 3840 \mu \mathrm{L})$, $10 \mathrm{mmol} \mathrm{L}^{-1} \mathrm{HCl}(0 ; 20 ; 40 ; 60 ; 80 \mu \mathrm{L}$, respectively) to give final $100 \mu \mathrm{mol} \mathrm{L}^{-1}$ RuIbp and 0; 50; 100; 150; $200 \mu \mathrm{mol} \mathrm{L}^{-1}$ $\mathrm{HCl}$, respectively. The mixtures were allowed to rest for $1 \mathrm{~min}$.

\section{Experiment 2 with sulfuric acid}

(i) Similar procedure to experiment 1a was followed starting from $10 \mathrm{~mol} \mathrm{~L}^{-1}$ sulfuric acid $(0 ; 40 ; 80 ; 120$; $160 \mu \mathrm{L}$, respectively) to give final $200 \mu \mathrm{mol} \mathrm{L} \mathrm{L}^{-1} \mathrm{RuIbp}$ and $0 ; 50 ; 100 ; 150 ; 200 \mu \mathrm{mol} \mathrm{L}^{-1} \mathrm{H}_{2} \mathrm{SO}_{4}$, respectively; (ii) similar procedure to experiment $1 \mathrm{~b}$ was followed starting from $5 \mathrm{~mol} \mathrm{~L}^{-1} \mathrm{H}_{2} \mathrm{SO}_{4}$ to give $100 \mu \mathrm{mol} \mathrm{L}{ }^{-1} \mathrm{RuIbp}$ and $0 ; 25 ; 50 ; 75 ; 100 \mu \mathrm{mol} \mathrm{L}^{-1} \mathrm{H}_{2} \mathrm{SO}_{4}$, respectively.

\section{Experiment 3 with acetic acid}

(a) $80 \mu \mathrm{L}$ volumes from $10 \mathrm{mmol} \mathrm{L} \mathrm{L}^{-1}$ RuIbp fresh ethanolic solution were separately added to Falcon tubes containing water $(3920 ; 3880 ; 3840 ; 3800 ; 3760 \mu \mathrm{L})$ and HAc $(0 ; 40 ; 80 ; 120 ; 160 \mu \mathrm{L}$, respectively), to give final $200 \mu \mathrm{mol} \mathrm{L}{ }^{-1}$ RuIbp and 0; 100; 200; 300; $400 \mu \mathrm{mol} \mathrm{L}^{-1}$ HAc, respectively, and allowed to rest for $1 \mathrm{~min}$; (b) the procedure was repeated by using $80 \mu \mathrm{L}$ from $5 \mathrm{mmol} \mathrm{L}^{-1}$ RuIbp ethanolic solution, water $(3920 ; 3900 ; 3880 ; 3860$; $3840 \mu \mathrm{L})$ and $10 \mathrm{mmol} \mathrm{L}^{-1} \mathrm{HAc}(0 ; 20 ; 40 ; 60 ; 80 \mu \mathrm{L}$, respectively) to give final $100 \mu \mathrm{mol} \mathrm{\textrm {L } ^ { - 1 }}$ RuIbp and 0; 50; 100; 150; $200 \mu \mathrm{mol} \mathrm{L}^{-1} \mathrm{HAc}$, respectively. In a separate experiment, $800 \mu \mathrm{L}$ from $1.0 \mathrm{mmol} \mathrm{\textrm {L } ^ { - 1 }}$ RuIbp fresh ethanolic solution diluted to $4 \mathrm{~mL}$ with $1 \%$ acetic acid solution was maintained under stirring for $30 \mathrm{~min}$ and analyzed by high-performance liquid chromatography (HPLC) to investigate possible dissociation of the ibuprofen ligand. The determination of the released ibuprofen was based on a calibration curve at $221 \mathrm{~nm}$ at the range 0.05-1.0 mg mL $\mathrm{mL}^{-1}$ HIbp.

\section{Behavior of Rulbp in the cell culture medium}

A $10 \mathrm{mmol} \mathrm{L}^{-1}$ stock solution of RuIbp in ethanol was freshly prepared and volumes of this solution $(10 ; 20 ; 40$; $80 \mu \mathrm{L}$ ) were added to distinct volumes (3990; 3980; 3960; $3920 \mu \mathrm{L}$, respectively) of the cell growth culture medium (DMEM, Dulbecco's modified Eagle medium, supplemented with $10 \%$ fetal bovine serum (FBS) and 5\% penicillinstreptomycin, all from Life Technologies, São Paulo, Brazil). The final mixtures containing 25; 50; 100; $200 \mu \mathrm{mol} \mathrm{L}-1$ RuIbp, respectively, and $0.25 ; 0.5 ; 1 ; 2 \%$ ethanol (v/v), respectively, were incubated at $37{ }^{\circ} \mathrm{C}$. The particle size was monitored in function of the time up to $24 \mathrm{~h}$.

\section{Quantification of ruthenium in the cell culture medium}

Seven samples were separately prepared by adding $60 \mu \mathrm{L}$ of $10 \mathrm{mmol} \mathrm{L}^{-1}$ fresh ethanolic RuIbp to $5940 \mu \mathrm{L}$ cell growth culture medium to give $100 \mu \mathrm{mol} \mathrm{L}^{-1}$ metallodrug final concentration and $1 \%$ ethanol. These samples were kept at $37{ }^{\circ} \mathrm{C}$ at different time periods $(0.5 ; 1,2,4,6,8$ and $24 \mathrm{~h}$ ), and after the required time point, $5 \mathrm{~mL}$ of each the solution (leaving any precipitate behind) was sent to inductively coupled plasma optical emission spectroscopy (ICP OES) analysis.

\section{Cell uptake}

The U87MG glioma cancer cells (American Type Culture Collection, ATCC) were incubated into 8 wells in 
24-well plate at the density $1 \times 10^{5}$ cells well $^{-1}$ in growth culture medium (DMEM, supplemented with 10\% FBS and $5 \%$ penicillin-streptomycin) for $24 \mathrm{~h}$ (in $5 \% \mathrm{CO}_{2}, 95 \%$ humidified air). The medium from each well was aspired and $495 \mu \mathrm{L}$ of fresh growth medium followed by $5 \mu \mathrm{L}$ from $10 \mathrm{mmol} \mathrm{L}^{-1}$ RuIbp (to give the final metallodrug concentration $100 \mu \mathrm{mol} \mathrm{L}^{-1}$ ) were added. The plate was incubated again at $37^{\circ} \mathrm{C}$ for $24 \mathrm{~h}$. For determination of the amount of metallodrug not taken up by cells, the medium from each well was aspired (total volume $4.0 \mathrm{~mL}$ ) and the Ru metal content was analyzed by ICP OES. For analysis of the cell captured metallodrug, the cells were washed with phosphate buffered saline (PBS, $0.25 \mathrm{~mL}$ ), trypsin (trypsin $0.025 \% /$ thylenediamine tetraacetic acid (EDTA) $0.02 \%$ ) was added to each well, and after 5 min incubation, the trypsinized solution (total volume $2.0 \mathrm{~mL}$ ) was sent to ICP OES analysis. For the precipitate, the amount of metallodrug in the plate was dissolved by adding $0.25 \mathrm{~mL}$ ethanol to each well and the solution (total volume $2.0 \mathrm{~mL}$ ) was sent to ICP OES analysis.

\section{Instrumentation and sample preparation}

Particle size (by DLS, dynamic light scattering) and zeta potential (ZP) values were measured in triplicate in a Malvern Zeta Sizer Nano-ZS. The time dependence of particle size in the growth culture medium was monitored after incubation at $37{ }^{\circ} \mathrm{C}$, up to $24 \mathrm{~h}$. The electronic absorption spectra were recorded on a Shimadzu model UV-2600 spectrophotometer coupled to a CPS-100 device for temperature control. The quartz cuvettes with $10 \mathrm{~mm}$ optical path were conventional cells for $2.5 \mathrm{~mL}$ samples or microcell for $500 \mu \mathrm{L}$ volumes. The suspensions were analyzed $1 \mathrm{~min}$ after the addition of the RuIbp ethanolic solution to water or culture medium. HPLC was conducted on a Shimadzu HPLC Prominence device with an LC-20AT liquid chromatographer, SIL-20A auto sampler, SPD-M20A diode array detector and other Prominence modules (reversed-phase, isocratic analysis, Lichrospher $100 \mathrm{RP}-18(5 \mu \mathrm{m}, 250 \times 4 \mathrm{~mm})$ column, acetonitrile/ $0.25 \mathrm{~mol} \mathrm{~L}^{-1}$ acetic acid, glacial (7:3, v/v) mobile phase, $25 \mu \mathrm{L}$ injection volume, at $1 \mathrm{~mL} \mathrm{~min}^{-1}$ and $35.0^{\circ} \mathrm{C}$ ). A calibration curve was built at $254 \mathrm{~nm}$ for 0.1 to $1.0 \mathrm{mg} \mathrm{mL}^{-1} \mathrm{HIbp}$. The transmission electron microscopy (TEM) images and energy-dispersive X-ray spectroscopy (EDX) spectra were recorded on a JEOL JEM 2100 LaB6 equipment (acceleration voltage, $200 \mathrm{kV}$; magnification, $\times 150,000)$ for the RuIbpNP nanoparticles dispersed on carbon using a Formvar carbon film on 200 mesh Cu grid (from Electron Microscopy Sciences), at the Analytical Center of the Institute of Chemistry, University of São Paulo
(IQ-USP). The electrospray ionization mass spectrometry (ESI-MS) experiments were performed on Bruker Daltonics Micro TOF equipment at the Analytical Center of IQ-USP. For ESI-MS spectra, the RuIbpNP nanoparticles were isolated by centrifugation in $30 \mathrm{kDa}$ Amicon ultra filters (Millipore) at $5000 \mathrm{rpm}$ and further diluted with methanol. The quantitative analysis of $\mathrm{Ru}$ (after mineralization/ opening the samples with aqua regia and heating them in digest block at $70{ }^{\circ} \mathrm{C}$ in sealed flasks) was performed by ICP OES in a Spectro Arcos equipment at the Analytical Center of IQ-USP.

\section{Results and Discussion}

The paddlewheel structured metal-metal multiply bonded compounds of formula $\left[\mathrm{Ru}_{2}\left(\mathrm{O}_{2} \mathrm{CR}\right)_{4} \mathrm{Cl}\right]$ show tendency to form multinuclear extended polymeric chains with the dinuclear units linked by chloride bridging axial ligands in the solid state. ${ }^{39,40}$ In solution, axially substituted species, such as neutral monosubstituted $\left[\mathrm{Ru}_{2}\left(\mathrm{O}_{2} \mathrm{CR}\right)_{4} \mathrm{Cl}(\mathrm{S})\right]$ or cationic disubstituted $\left[\mathrm{Ru}_{2}\left(\mathrm{O}_{2} \mathrm{CR}\right)_{4}(\mathrm{~S})_{2}\right]^{+}$, may predominate due to ligand substitution reactions in which the relatively labile chloride exchanges with the solvent (S). The breakage of the polymeric chain might be one of the features that affects the solubility of these compounds. However, the nature of the equatorial ligands may be determinant to favor or do not favor the compound solubility. The tetrakis(acetate)-compound, $\left[\mathrm{Ru}_{2}\left(\mathrm{O}_{2} \mathrm{CCH}_{3}\right)_{4} \mathrm{Cl}\right]$, for instance, is readily soluble in water, differently from the equatorially substituted RuIbp in which the presence of the ibuprofenate ligands impairs the aqueous solubility while improves the drug solubility in ethanol. Previous studies from our group ${ }^{34}$ showed that the solubilities of three axially modified RuIbp complexes, i.e., $\left[\mathrm{Ru}_{2}(\mathrm{Ibp})_{4} \mathrm{Cl}\right]$, $\left[\mathrm{Ru}_{2}(\mathrm{Ibp})_{4} \mathrm{CF}_{3} \mathrm{SO}_{3}\right]$ and $\left[\mathrm{Ru}_{2}(\mathrm{Ibp})_{4}(\mathrm{EtOH})_{2}\right] \mathrm{PF}_{6}$, are very similar despite the last one be formed by cationic dinuclear units (with non-coordinated $\mathrm{PF}_{6}{ }^{-}$anion as counter ion) in contrast to the other two compounds which tend to form polymeric chains in the solid state.

Partition coefficient of Rulbp and solubility in water/organic solvent

In fact, the moiety containing the aromatic ring and the carbon tail in the molecular structure of the ibuprofen ligands (Figure 1) may contribute to the hydrophobicity of these complexes leading to the poor solubility in water. The value of the partition coefficient for RuIbp $\left(\log \mathrm{P}_{\text {octanol/water }}=2.0\right)$, which is very close to the value found here for the HIbp drug $\left(\log \mathrm{P}_{\text {octanol/water }}=2.3\right)$, supports the highly hydrophobic character of the metallodrug. 
In addition, the studies about the solubility of the metallodrug in alcohol/water (expressed in plots of drug concentration $v s$. solvent composition in Figure 2) indicate that at least $70 \%$ alcohol is needed to find significant concentration of RuIbp in solution when the compound is directly dissolved in these mixed solvents. Above $70 \%$ alcohol, the drug solubility increases exponentially as the organic solvent percentage increases and shows a dependency on the nature of the alcohol. Moreover, the solubilization of $100 \mu \mathrm{mol} \mathrm{L} \mathrm{L}^{-1}$ RuIbp occurred at about $80 \%$ ethanol when the compound was directly dissolved in the organic/water mixed solvent.

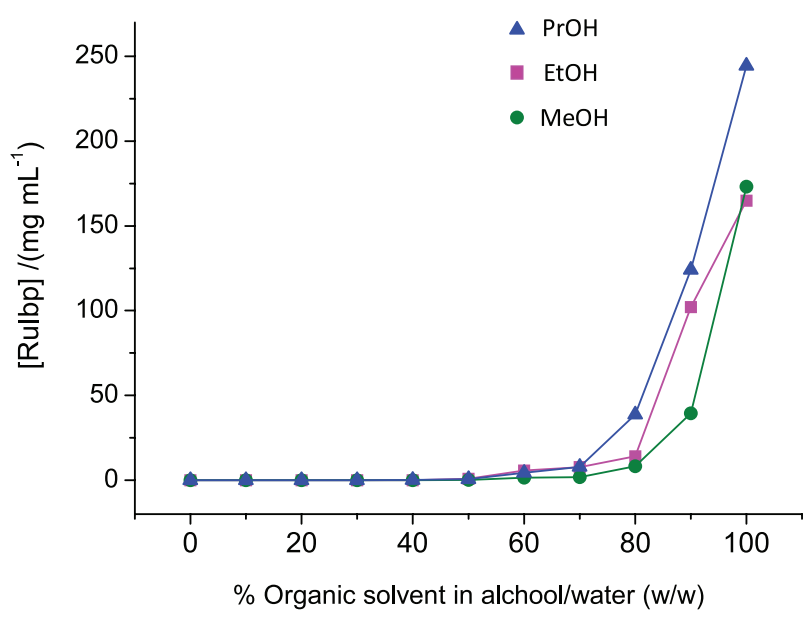

Figure 2. Solubility of the RuIbp compound in alcohol/water in function of the percentage of alcohol in the mixed solvent.

\section{Behavior of Rulbp in 1-5\% ethanol/water: RulbpNP nanoparticles}

Ethanol is commonly used as a solvent in biological assays to prepare stock solutions of water poorly soluble drugs (including metal-based drugs) which are added to the aqueous growth culture medium in the experiments in vitro. It was also selected here for the studies of biological activity of RuIbp due to the good solubility of the metallodrug in this solvent. In contrast to the experiments described above for solubility in alcohol/water (where the compound is directly dissolved in the mixed solvent), in the biological assays the metallodrug is first dissolved in ethanol to prepare the stock solution, and after that, volumes of this stock solution are added to the aqueous cell growth culture medium. The drug low aqueous solubility, however, was still a matter of concern in the biological assays conditions.

The color of the RuIbp solid is brown while solutions containing the compound dissolved in ethanol are yellowish. However, under certain conditions, the addition of the RuIbp yellowish ethanolic solution to water resulted in color change to pinkish. A more detailed examination using a laser beam showed Tyndall effect suggesting the presence of small particles, as can be seen in Figure 3 for mixtures containing 100 (Figure 3a) and $200 \mu \mathrm{mol} \mathrm{L}^{-1}$ (Figure 3b) RuIbp. These initial findings suggested that RuIbp was capable of forming self-assembled nanoparticles (RuIbpNP nanoparticles). The experimental conditions based on the dissolution of RuIbp in a solvent in which the drug is soluble (ethanol) and further addition of this solution to a solvent in which the drug is insoluble (water) are actually associated to the bottom-up technique based on solvent anti-solvent precipitation using two miscible solvents which favors instantaneous precipitation of nanoparticles. ${ }^{41}$ (a)

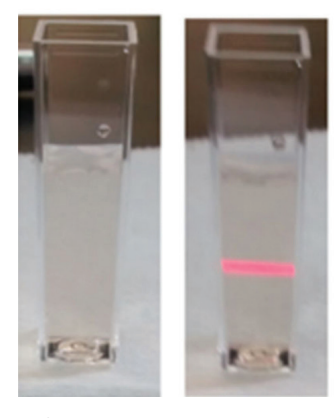

(b)

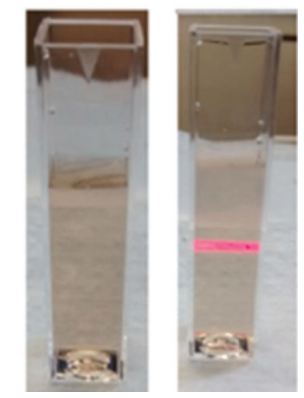

Figure 3. Effect of laser light in suspensions of RuIbp in ethanol/water for metallodrug concentrations: (a) 100; (b) $200 \mu \mathrm{mol} \mathrm{L}-1$.

To explore the phenomenon in more detail, the solvent anti-solvent method was used to prepare RuIbpNP nanoparticles based on the conditions observed for ethanol/water mixtures in which small volumes of ethanolic solutions of RuIbp are added to water. In the first experiment, the concentration of RuIbp was varied from 100 to $500 \mu \mathrm{mol} \mathrm{L}{ }^{-1}$. The results obtained at $25^{\circ} \mathrm{C}$ (Table 1) revealed particle size (mean diameter) around $100 \mathrm{~nm}$ and polydispersity index (PDI) value at $0.1-0.2$ suggesting narrowly monodisperse particles for RuIbp concentrations up to $300 \mu \mathrm{mol} \mathrm{L} \mathrm{L}^{-1}$. An increase on the particle size (> $150 \mathrm{~nm}$ ) accompanied by increased PDI (around 0.3) was observed for higher concentrations. The particle size of the RuIbpNP nanoparticles measured for drug concentrations 100 and $200 \mu \mathrm{mol} \mathrm{L}-1$ at $37^{\circ} \mathrm{C}$ were also close to $100 \mathrm{~nm}$, suggesting no significant changes with the temperature increase. The zeta potential at $+40-50 \mathrm{mV}$ indicates good stability for these nanoparticles. In the second experiment, the RuIbp concentrations were fixed at 100 and $200 \mu \mathrm{mol} \mathrm{L} \mathrm{L}^{-1}$ while ethanol percentage in the final ethanol/water mixture varied from 1 to $5 \%$. The results of measurements at $25{ }^{\circ} \mathrm{C}$ (Table 1) indicate no significant changes on particle sizes which were maintained at about $100 \mathrm{~nm}$ for both drug concentrations 
Table 1. Average particle size, polydispersity index (PDI), and zeta potential (ZP) values for the RuIbpNP nanoparticles in ethanol/water and ethanol/ culture medium

\begin{tabular}{|c|c|c|c|c|c|c|c|}
\hline & $\begin{array}{c}{[\text { RuIbp] / }} \\
\left.(\mu \mathrm{mol} \mathrm{L})^{-1}\right)\end{array}$ & $\begin{array}{c}\text { EtOH in } \\
\text { EtOH/water / \% }\end{array}$ & $\begin{array}{l}\text { Particle size } \pm \text { St. } \\
\text { dev., } 25^{\circ} \mathrm{C} / \mathrm{nm}\end{array}$ & PDI \pm St. dev. & $\begin{array}{c}\text { Particle size } \pm \text { St. } \\
\text { dev., } 37^{\circ} \mathrm{C} / \mathrm{nm}\end{array}$ & PDI \pm St. dev. & $\mathrm{ZP}, 25^{\circ} \mathrm{C} / \mathrm{mV}$ \\
\hline \multirow{15}{*}{ EtOH/water } & 100 & 1 & $104.2 \pm 0.4$ & $0.181 \pm 0.006$ & $98.0 \pm 1.2$ & $0.119 \pm 0.017$ & $+(45.0 \pm 0.8)$ \\
\hline & 200 & 2 & $116.4 \pm 0.5$ & $0.146 \pm 0.004$ & $97.2 \pm 1.1$ & $0.121 \pm 0.011$ & $+(42.9 \pm 1.9)$ \\
\hline & 300 & 3 & $100.2 \pm 0.2$ & $0.141 \pm 0.013$ & n.d. & n.d. & $+(51.1 \pm 0.7)$ \\
\hline & 400 & 4 & $154.5 \pm 2.5$ & $0.325 \pm 0.037$ & n.d. & n.d. & $+(52.0 \pm 1.4)$ \\
\hline & 500 & 5 & $192.7 \pm 1.6$ & $0.260 \pm 0.006$ & n.d. & n.d. & $+(47.5 \pm 1.5)$ \\
\hline & \multirow{5}{*}{100} & 1 & $97.72 \pm 1.40$ & $0.280 \pm 0.006$ & n.d. & n.d. & $+(40.7 \pm 0.5)$ \\
\hline & & 2 & $88.19 \pm 0.62$ & $0.157 \pm 0.008$ & n.d. & n.d. & $+(43.3 \pm 1.3)$ \\
\hline & & 3 & $109.6 \pm 0.8$ & $0.126 \pm 0.020$ & n.d. & n.d. & $+(43.6 \pm 2.5)$ \\
\hline & & 4 & $98.30 \pm 0.02$ & $0.154 \pm 0.011$ & n.d. & n.d. & $+(41.9 \pm 2.2)$ \\
\hline & & 5 & $123.0 \pm 0.8$ & $0.127 \pm 0.008$ & n.d. & n.d. & $+(45.2 \pm 0.4)$ \\
\hline & \multirow{5}{*}{200} & 1 & $108.5 \pm 0.8$ & $0.218 \pm 0.005$ & n.d. & n.d. & $+(48.4 \pm 1.8)$ \\
\hline & & 2 & $105.7 \pm 0.1$ & $0.160 \pm 0.003$ & n.d. & n.d. & $+(49.9 \pm 5.0)$ \\
\hline & & 3 & $106.2 \pm 1.5$ & $0.133 \pm 0.02$ & n.d. & n.d. & $+(52.9 \pm 2.9)$ \\
\hline & & 4 & $116.0 \pm 0.8$ & $0.140 \pm 0.015$ & n.d. & n.d. & $+(46.9 \pm 2.5)$ \\
\hline & & 5 & $145.8 \pm 0.8$ & $0.133 \pm 0.004$ & n.d. & n.d. & $+(39.1 \pm 0.9)$ \\
\hline \multirow{4}{*}{$\begin{array}{l}\text { EtOH/cell culture } \\
\text { medium }\end{array}$} & 25 & 0.25 & $128.8 \pm 1.4$ & $0.287 \pm 0.006$ & $147.1 \pm 2.6$ & $0.302 \pm 0.006$ & \\
\hline & 50 & 0.5 & $150.3 \pm 1.9$ & $0.264 \pm 0.028$ & $179.6 \pm 2.2$ & $0.248 \pm 0.018$ & \\
\hline & 100 & 1 & $183.6 \pm 1.4$ & $0.212 \pm 0.001$ & $180.0 \pm 0.4$ & $0.226 \pm 0.005$ & \\
\hline & 200 & 2 & $208.6 \pm 0.7$ & $0.204 \pm 0.014$ & $186.9 \pm 1.0$ & $0.191 \pm 0.009$ & \\
\hline
\end{tabular}

St.dev.: standard deviation determined from triplicates of measurements; n.d.: not determined.

and all ethanol percentages, except for a slight increase at $5 \%$ ethanol (120-145 nm). The PDI values around 0.1-0.3 suggest narrowly monodisperse particles. The zeta potential values were also at the range +40 to $+50 \mathrm{mV}$, indicating the maintenance of the stability for the nanoparticles for all the ethanol/water compositions varying the ethanol percentage.

The electronic absorption spectrum of the aqueous suspension of RuIbpNP nanoparticles shows the $\pi(\mathrm{Ru}-\mathrm{O}) \rightarrow \pi *\left(\mathrm{Ru}_{2}\right)$ electronic transition at $\lambda_{\text {max }}$ about $460 \mathrm{~nm}$ (Figure 4a) and a shoulder at 500-600 nm. It resembles the spectrum of the solid compound except for the band shift to lower wavelength, in relation to the solid $(484 \mathrm{~nm})$, which may indicate the breakage of the axially bridged chain accompanied by the substitution of one chloride ligand to give monosolvated species, since the substitution of both chloride ligands by ethanol molecules would shift the band to about $420 \mathrm{~nm} .{ }^{34}$ The presence of an acid in the ethanol/water mixtures leads to significant spectral changes. Figure 4 shows the visible band shifts to higher energy ( $\lambda_{\max }$ ca. $450 \mathrm{~nm}$ ) while the intensity of the shoulder at 500-600 nm decreases by increasing the $\mathrm{HCl}$ concentration ( $\mathrm{pH} 3.4-4.5$ ). In $\mathrm{H}_{2} \mathrm{SO}_{4}$ ( $\left.\mathrm{pH} 3.4-4.5\right)$, the band shifted to about $420 \mathrm{~nm}$ and the shoulder disappeared faster as the acid concentration increased. Conversely, the presence of HAc ( $\mathrm{pH} 4.0-5.0)$ caused less pronounced spectral changes with no significant shift of the band at about $450 \mathrm{~nm}$ and a slight decrease in the shoulder intensity. The behavior observed by modifying the nature of the acid might be related to changes in the axial position of the $\left[\mathrm{Ru}_{2}(\mathrm{Ibp})_{4}\right]$ framework. The hydrochloric acid introduces excess of chloride coordinating ligand into the mixture, thus may contribute to avoid the complete dissociation of this ligand, while no coordinating ligand is provided by the sulfuric acid what may promote the dissociation of both chlorides. The acetic acid in its turn would favor the replacement of the equatorial ibuprofenate ligand by acetate, but this process was not much significant since HPLC analysis detected only $10 \%$ ibuprofen released after 30 min stirring in the presence of $1 \%$ HAc. Based on these findings it is plausible to infer that the $\left[\mathrm{Ru}_{2}(\mathrm{Ibp})_{4}\right]$ framework is mostly maintained while changes on the axial positions may occur. The spectral changes in the presence of acids might be associated to possible protonation of potential axial ligands such as ethanol, water or even hydroxide ions. It is noteworthy that the replacement of labile ligands such as chloride by hydroxide ions and/or water molecules, resulting in hydrolysis and generating poly-oxo species, has been reported ${ }^{42}$ for some poorly water 
stable $\mathrm{Ru}^{\mathrm{III}}$ anticancer compounds, although the presence of oligomeric species seems to not impair the overall antitumor activity, at least of the NAMI-A.

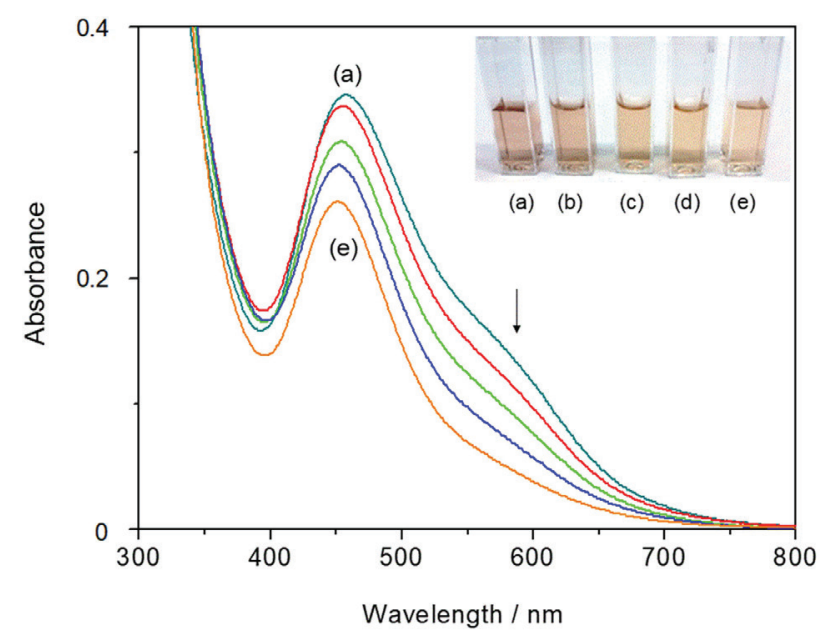

Figure 4. Electronic spectra of RuIbp $200 \mu \mathrm{mol} \mathrm{L}^{-1}$ in: (a) water; and acidic solutions containing (b) 100; (c) 200; (d) 300 and (e) $500 \mu \mathrm{mol} \mathrm{L}^{-1} \mathrm{HCl}$.

The particle size of the suspension for $100 \mu \mathrm{mol} \mathrm{L}-1$ RuIbp decreased to about $40 \mathrm{~nm}$ in the presence of hydrochloric acid or sulfuric acid, and to about $55 \mathrm{~nm}$ in the presence of acetic acid, indicating that the original RuIbpNP nanoparticles are no longer present in acidic medium. Moreover, preliminary studies show that if the solution in acetic acid is diluted with water, the yellow color is restored to pinkish, suggesting that the formation of RuIbpNPs might be reversible depending on the $\mathrm{pH}$ in the presence of this acid. Conversely, in the presence of sodium hydroxide basic solution, the compound was not stable. Overall, these studies indicate the RuIbpNPs show higher stability around neutral $\mathrm{pH}$ value.

The TEM images (Figure 5) show that the RuIbpNP nanoparticles are nearly spherical in shape and also support the results from DLS particle size measurements by confirming the particle mean diameter at about $100 \mathrm{~nm}$. The EDX spectrum shows evidence for the presence of Ru metal in the nanoparticle (point (a)), while in the substrate (point (b)) outside the nanoparticle no signal for Ru was found. The EDX spectrum also shows signal for chlorine what suggests the maintenance of the chloride ligand in the structure of the metallodrug in the RuIbpNP nanoparticles.

Behavior of RulbpNP nanoparticles in cell growth culture medium

Importantly, we have found that the ethanol/water solvent composition favoring the formation of the RuIbpNP nanoparticles when the ethanolic solution of RuIbp is added to water is similar to that of the biological cell treatment where small volumes of the RuIbp ethanolic stock solution are added to the cell growth culture medium. Moreover, the 100 and $200 \mu \mathrm{mol} \mathrm{L}{ }^{-1}$ RuIbp concentrations which gave the best nanoparticle parameters are exactly
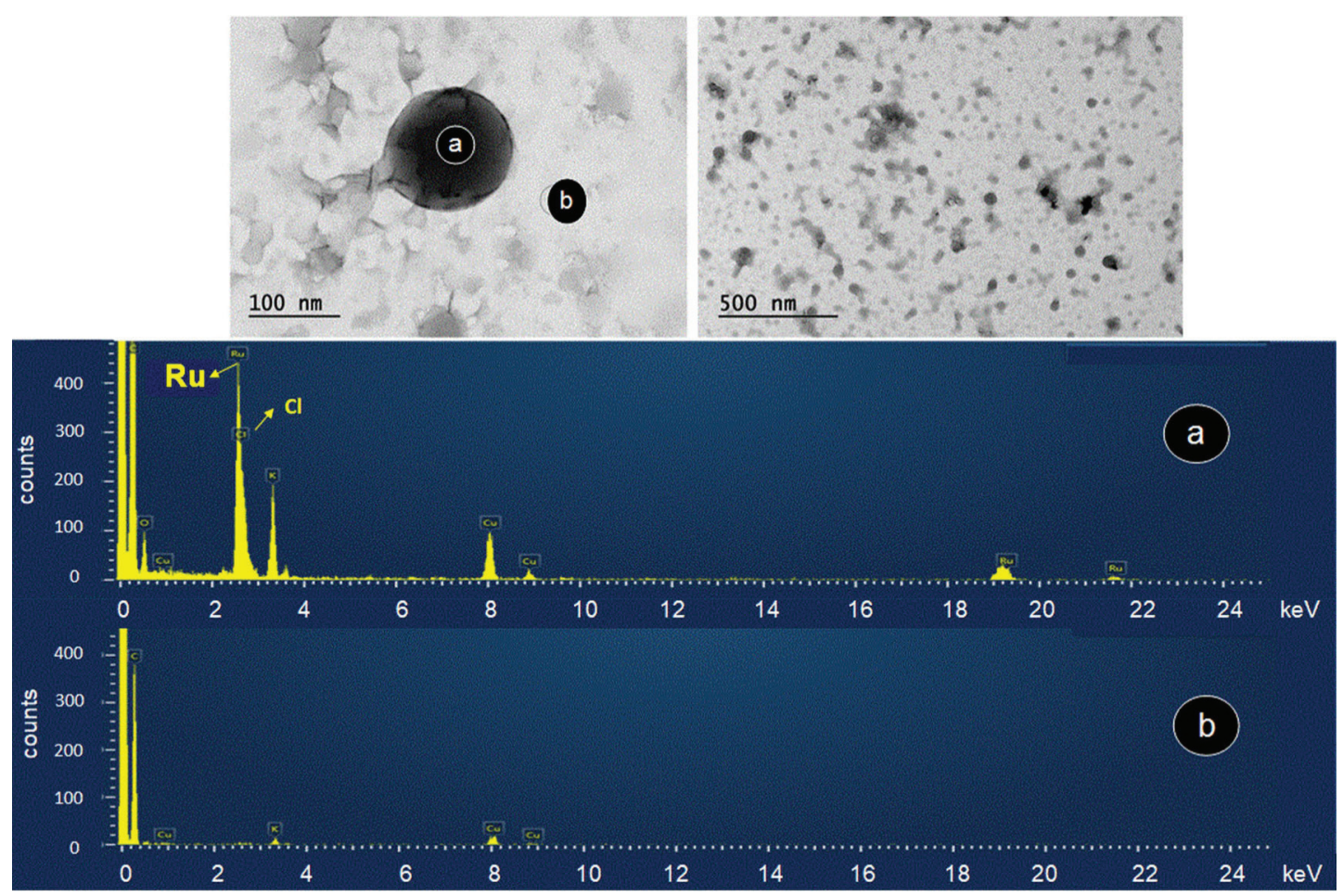

Figure 5. TEM images and EDX spectra of points (a) and (b) of the RuIbpNP nanoparticles. 
at the concentration range corresponding to the in vitro antiproliferative activity of the metallodrug against the glioma cell lines. ${ }^{28,29,34}$ Then, to verify how the metallodrug would behave in the biological medium, we have performed experiments by adding the ethanolic solutions of RuIbp into the cell growth culture medium instead of using only water. The particle size of the RuIbpNPs formed in suspensions having $25-200 \mu \mathrm{mol} \mathrm{L}{ }^{-1}$ RuIbp are at the range $150-200 \mathrm{~nm}$, for both room temperature $\left(25^{\circ} \mathrm{C}\right)$ and physiological temperature $\left(37^{\circ} \mathrm{C}\right)$. The PDI values around 0.2 for the highest concentrations (100 and $200 \mu \mathrm{mol} \mathrm{L}{ }^{-1}$ RuIbp) suggest narrow particle size distribution. The increase on RuIbpNP nanoparticles particle size in the culture medium, in comparison with the mean diameter in aqueous suspension (about $100 \mathrm{~nm}$ ), has also been observed before for the systems containing the metallodrug encapsulated into biocompatible terpolymer-lipid nanoparticles. ${ }^{19}$ The particle size in the growth medium kept at $37^{\circ} \mathrm{C}$ (Figure 6) remained unchanged up to $24 \mathrm{~h}$ giving evidence for the good colloidal stability of the RuIbpNP nanoparticles within the period of time of incubation before refreshing the culture medium and drug treatment. Similar experiments by adding the ethanolic solution of RuIbp to aqueous solution of sodium chloride at the same salt concentration as found in the DMEM led to complete precipitation of the metallodrug. Thus, it is important to note that, despite the excess of chloride (that would favor precipitation), the presence of a variety of substances in the cell growth medium may be relevant to favor the formation of the RuIbpNP nanoparticles.

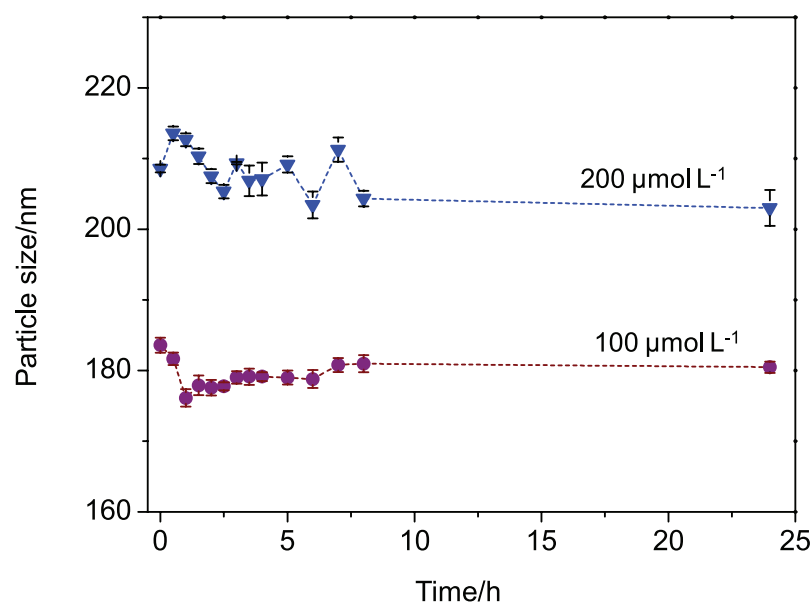

Figure 6. Particle size as a function of the time in the cell growth culture medium at $37^{\circ} \mathrm{C}$ for 100 and $200 \mu \mathrm{mol} \mathrm{L}{ }^{-1}$ RuIbp concentrations.

The ESI-MS(+) spectrum of the RuIbpNP nanoparticles in aqueous suspension (Figure 7a) shows the maximum $\mathrm{m} / \mathrm{z}$ at 1024.3 and characteristic isotopic distribution of $\mathrm{Ru}$ being assignable to the $\left[\mathrm{Ru}_{2}\left(\mathrm{C}_{13} \mathrm{H}_{17} \mathrm{O}_{2}\right)_{4}\right]^{+}$ionic fragment (calculated $m / z=1024.3) .{ }^{34}$ The same fragment was detected for suspensions of RuIbpNP nanoparticles in both cell growth culture media, freshly prepared (Figure 7b) and incubated at $37^{\circ} \mathrm{C}$ for $24 \mathrm{~h}$ (Figure $7 \mathrm{c}$ ). The appearance of the peak at $m / z 1024.3$ corroborates with the maintenance of the $\left[\mathrm{Ru}_{2}(\mathrm{Ibp})_{4}\right]$ paddlewheel structured framework carrying four ibuprofen drugs per dimetallic core in the nanoparticles.

The amount of Ru metal monitored during the incubation time of RuIbp in the cell culture medium is shown in Table 2 for 100 and $200 \mu \mathrm{mol} \mathrm{L}{ }^{-1}$ RuIbp initial concentrations. No significant changes in the content of $\mathrm{Ru}$ was found what suggests that the RuIbpNP nanoparticles remains suspended up to $24 \mathrm{~h}$, which is the time cycle of cell assays before culture medium and drug treatment are refreshed. The concentrations of RuIbp calculated from the number of mol of Ru metal are around 87 and $165 \mu \mathrm{mol} \mathrm{L}{ }^{-1}$ for 100 and $200 \mu \mathrm{mol} \mathrm{L}{ }^{-1} \mathrm{RuIbp}$ initial concentrations, respectively, indicating that about $85 \%$ of the metallodrug remains suspended in the cell culture medium in the form of RuIbpNP nanoparticles. Therefore, despite the hydrophobicity, high percentage of metallodrug still remains in the culture medium without precipitating. This finding along with the results from particle size time monitoring and the ESI-MS spectra supports that the RuIbpNP nanoparticles are stable in culture medium up to $24 \mathrm{~h}$.

\section{Uptake of RulbpNP nanoparticles by cells}

The experiment of cellular uptake was performed in the U87MG human glioblastoma cells by adding $5 \mu \mathrm{L}$ $10 \mathrm{mmol} \mathrm{L}^{-1}$ RuIbp fresh ethanolic solution to $495 \mu \mathrm{L}$ culture medium to give $100 \mu \mathrm{mol} \mathrm{L} \mathrm{L}^{-1} \mathrm{RuIbp}$ and $1 \%$ ethanol. The cell uptake of $\mathrm{Ru}$ was evaluated considering that besides the amount of drug captured by the cells, part of the drug may still remain in the culture medium and/or precipitate over the time. The ICP OES analyses of $\mathrm{Ru}$ indicated that about $6 \%$ metallodrug was captured by the cells (trypsinized cells). The amount of Ru which remains suspended (54\%) without agglomeration after $24 \mathrm{~h}$, although lower than that $(85 \%)$ of culture medium without cell, is still high considering the RuIbp hydrophobicity and supports the formation of RuIbpNP nanoparticles also in presence of the cells. The amount of precipitated metallodrug was about $12-40 \%(12 \% \mathrm{Ru}$ was found in the residue dissolved in ethanol, and the missing $\mathrm{Ru}$ was probably left as a precipitate attached to the plate even after the addition of ethanol). These findings suggest that the suspension of nanoparticles may play key role in keeping the system stable enough to promote the metallodrug cell uptake in the time cycle of cell assays before refreshing culture medium and drug treatment. 

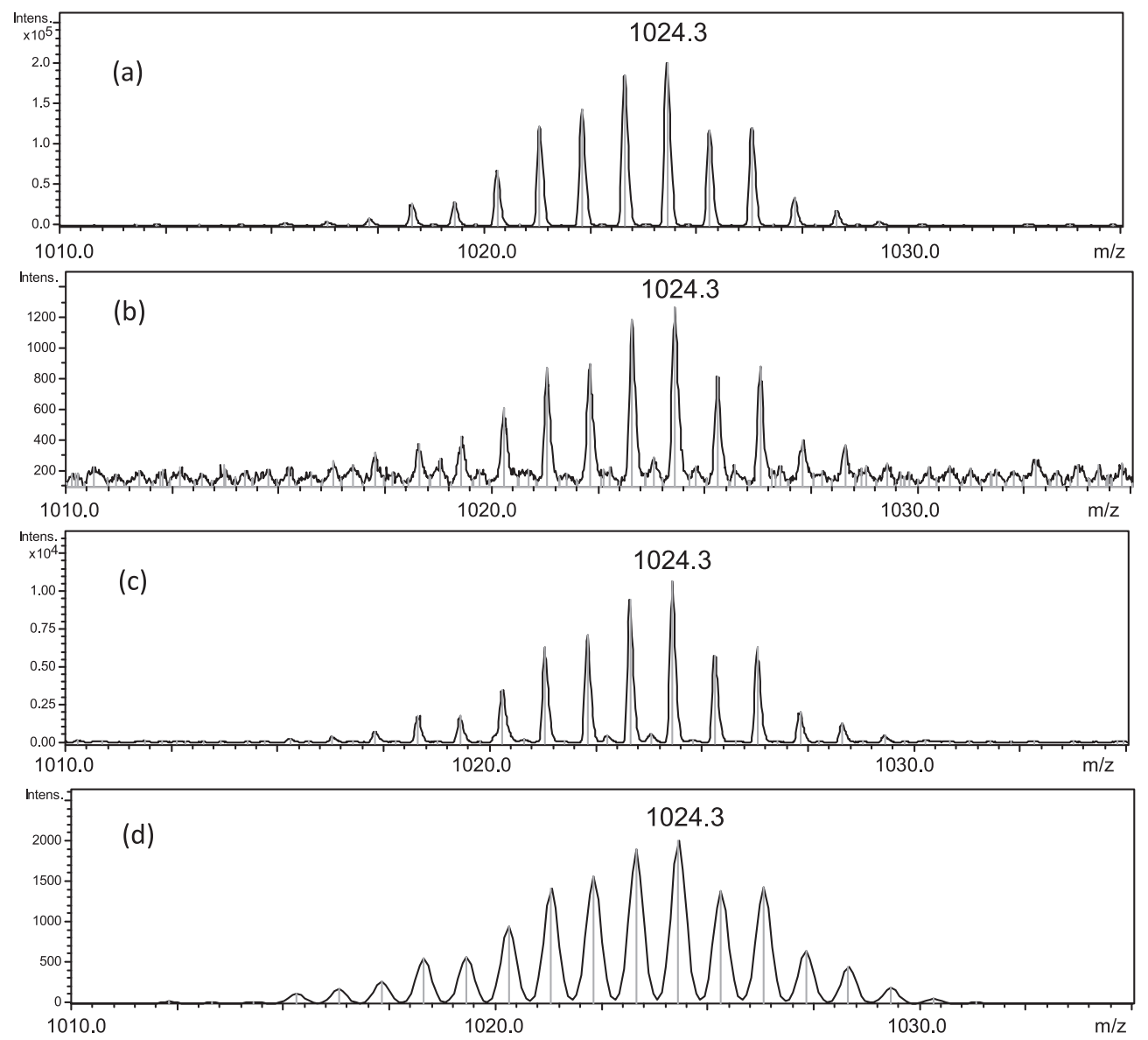

Figure 7. ESI-MS(+) spectra of RuIbpNP nanoparticles in (a) aqueous suspension; (b) fresh culture medium; (c) culture medium after incubation at $37{ }^{\circ} \mathrm{C}$ for $24 \mathrm{~h}$; (d) simulated MS pattern for the $\left[\mathrm{Ru}_{2}\left(\mathrm{C}_{13} \mathrm{H}_{17} \mathrm{O}_{2}\right)_{4}\right]^{+}$ionic fragment.

Table 2. Concentrations of Ru metal in function of the incubation time in cell growth culture medium (as determined by ICP OES) and corresponding calculated concentrations of the RuIbp metallodrug for the experiments performed at 100 and $200 \mu \mathrm{mol} \mathrm{L}{ }^{-1}$ Rulbp initial concentrations

\begin{tabular}{lccc}
\hline $\begin{array}{l}{[\text { RuIbp }]_{\text {initial }} /} \\
\left.(\mu \mathrm{mol} \mathrm{L})^{-1}\right)\end{array}$ & time $/ \mathrm{h}$ & $\begin{array}{c}{[\mathrm{Ru}]_{\text {final }}(\mathrm{ICP} \text { OES }) /} \\
\left(\mathrm{mg} \mathrm{L}^{-1}\right)\end{array}$ & $\begin{array}{c}{[\mathrm{RuIbp}]_{\text {final }} /} \\
\left(\mu \mathrm{mol} \mathrm{L}^{-1}\right)\end{array}$ \\
\hline \multirow{4}{*}{100} & 1.5 & $18.0 \pm 0.2$ & $84.1 \pm 1.0$ \\
& 1 & $19.0 \pm 0.3$ & $89.0 \pm 1.5$ \\
& 2 & $18.6 \pm 0.1$ & $86.7 \pm 0.5$ \\
& 4 & $18.9 \pm 0.2$ & $88.5 \pm 0.9$ \\
& 6 & $19.1 \pm 0.4$ & $89.4 \pm 2.0$ \\
& 8 & $19.1 \pm 0.1$ & $89.4 \pm 0.3$ \\
& 24 & $17.7 \pm 0.1$ & $82.7 \pm 0.3$ \\
\hline \multirow{4}{*}{00} & 2 & $34.5 \pm 0.2$ & $170 \pm 1$ \\
& 6 & $35.5 \pm 0.7$ & $176 \pm 4$ \\
& 8 & $31.0 \pm 0.1$ & $154 \pm 1$ \\
& 24 & $32.9 \pm 0.2$ & $162 \pm 1$ \\
\hline
\end{tabular}

ICP OES: inductively coupled plasma optical emission spectroscopy.

\section{Conclusions}

The partition coefficient of the RuIbp metallodrug $(\log \mathrm{P}($ in octanol/water $)=2.0)$ was found to be close to that of the HIbp drug (2.3). The investigation of the solubility of RuIbp in alcohol/water mixed solvent (with methanol, ethanol, propanol) showed that at least $70 \%$ alcohol is necessary to promote significant dissolution of the metallodrug when the solid is added directly into the solvent-cosolvent mixture. However, when the RuIbp metallodrug is firstly dissolved in small amount of ethanol and the drug ethanolic solution is added to water to give $1-5 \%$ ethanol, spontaneous generation of self-assembled RuIbpNP nanoparticles is observed. These nanoparticles show particle size (mean diameter) about $100 \mathrm{~nm}$, PDI 0.1-0.2, and zeta potential around $+40 \mathrm{mV}$ in aqueous suspension. Spectroscopic studies corroborate with the maintenance of the $\left[\mathrm{Ru}_{2}(\mathrm{Ibp})_{4}\right]$ framework pointing to possible axial changes during the nanoparticle formation. The presence of acids led to spectral changes which indicate that the stability of the RuIbpNP nanoparticles is higher around neutral $\mathrm{pH}$. TEM image reveals that the nanoparticles are nearly spherical in shape and the EDX spectra supports the presence of the Ru besides indicating the presence of $\mathrm{Cl}$ in the nanoparticles. In cell growth culture medium, the nanoparticles showed mean dimeter about $180 \mathrm{~nm}$ at $25^{\circ} \mathrm{C}$ 
and at the physiological temperature $\left(37^{\circ} \mathrm{C}\right)$, and the PDI around 0.2 suggested narrow particle size distribution. The particle size remained unchanged in growth culture medium at $37^{\circ} \mathrm{C}$ up to $24 \mathrm{~h}$ giving evidence for the good colloidal stability of the RuIbpNP nanoparticles within the time cycle before refreshing culture medium and drug treatment in biological assays. The integrity of the $\left[\mathrm{Ru}_{2}(\mathrm{Ibp})_{4}\right]$ paddlewheel structured unit (bearing four ibuprofenate drug ligands per diruthenium core) in the culture medium was confirmed by mass spectrometry. Quantification of $\mathrm{Ru}$ indicated significant amount of the metallodrug in suspension ( $85 \%$ in culture medium in the absence of cells; $54 \%$ in the presence of cells) thus supporting the presence of RuIbpNP nanoparticles in the medium with cells. The uptake by U87MG human glioblastoma cells was $6 \%$ after $24 \mathrm{~h}$ treatment.

The spontaneous nanosizing of RuIbp to form nanosuspensions in cell growth medium might explain the anticancer activity of this highly hydrophobic metallodrug. The phenomenon may play key role in keeping the system stable enough to avoid complete drug precipitation or drug degradation, thus providing conditions to favor metallodrug cell uptake within the time cycle of cell assays. This data supports our previous findings ${ }^{19}$ that the nanoencapsulation as RuIbp-loaded TPLNs leads to increased cellular uptake $(25 \%)$ in relation to the free metallodrug $(6 \%)$ by the U87MG cells at $24 \mathrm{~h}$, thus contributing to enhance the antiproliferative effects, probably, in part, by overcoming the poor-water drug solubility. Although in both of cases the metallodrug showed time and dose-dependent behavior inhibiting cell proliferation with best effect at $72 \mathrm{~h}$, significant decrease on cell number was found at about $10 \mu \mathrm{mol} \mathrm{L} \mathrm{L}^{-1}$ RuIbp in RuIbploaded TPLNs,${ }^{19}$ while similar effect was found at ten-fold higher RuIbp concentration (about $100 \mu \mathrm{mol} \mathrm{L}^{-1}$ ) for the free metallodrug. ${ }^{34}$ In addition, the tendency of generating selfassembled nanoparticles might take advantage of the EPR effect in vivo, considering that RuIbp succeed in reducing about $45 \%$ the tumor area in rat $\mathrm{C} 6$ orthotopic glioma. ${ }^{32}$ The present findings expand the knowledge on the behavior of RuIbp, opening new directions to exploit the properties of this metallodrug targeting cancer therapy.

\section{Acknowledgments}

The authors gratefully acknowledge the financial support from: Fundação de Amparo à Pesquisa do Estado de São Paulo [FAPESP, research grants to D. O. S. (2014/23047-5; 2018/00297-4); Doctorate fellowship to S. R. A. (2014/23481-7); Scientific Initiation fellowship to M. H. (2016/23028-6)]; Conselho Nacional de Desenvolvimento Científico e Tecnológico [CNPq, productivity fellowship to D. O. S. (305914/2015-4; 303103/2018-3; Doctorate fellowship to I. M. C.)]; Coordenação de Aperfeiçoamento de Pessoal de Nível Superior [CAPES, Doctorate fellowship to Hanif-Ur-Rehman (33002010191P0)]. The authors sincerely acknowledge Dr Alison Colquhoun at the Institute of Biomedical Sciences at USP for allowing the use of the facilities in her laboratory to conduct the cell biological assays, and MSc Alfredo Duarte at the Analytical Center of IQ-USP for the help with TEM experiments.

\section{References}

1. Alessio, E.; Bioinorganic Medicinal Chemistry; Wiley-VCH Verlag \& Co. KGaA: Weinheim, 2011.

2. Silva, D. O. In Frontiers in Anti-Cancer Drug Discovery, vol. 4; Atta-ur-Rahman; Choudhary, M. I., eds.; Bentham Science Publishers Ltd.: Sharjah, 2014, p. 88.

3. Coverdale, J. P. C.; Laroiya-McCarron, T.; Canelón, I. R.; Inorganics 2019, 7, 31.

4. Alessio, E.; Messori, L.; Molecules 2019, 24, 1995.

5. Brabec, V.; Kasparkova, J.; Coord. Chem. Rev. 2018, 376, 75.

6. Zhang, P.; Sadler, P. J.; J. Organomet. Chem. 2017, 839, 5.

7. Alessio, E.; Eur. J. Inorg. Chem. 2017, 1549.

8. Nazarov, A. A.; Hartinger, C. G.; Dyson, P. J.; J. Organomet. Chem. 2014, 751, 251.

9. Bergamo, A.; Gaiddon, C.; Schellens, J. H. M.; Beijnen, J. H.; Sava, G.; J. Inorg. Biochem. 2012, 106, 90.

10. Hartinger, C. G.; Metzler-Nolte, N.; Dyson, P. J.; Organometallics 2012, 31, 5677.

11. Sava, G.; Bergamo, A.; Dyson, P. J.; Dalton Trans. 2011, 40, 9069.

12. Silva, D. O.; Anti-Cancer Agents Med. Chem. 2010, 10, 312.

13. Ang, W. H.; Dyson, P. J.; Eur. J. Inorg. Chem. 2006, 20, 4003.

14. Pöthig, A.; Casini, A.; Theranostics 2019, 9, 3150.

15. Wang, X.; Guo, Z.; Chem. Soc. Rev. 2013, 42, 202.

16. Poursharifi, M.; Wlodarczyk, M. T.; Mieszawska, A. J.; Inorganics 2019, 7, 2.

17. Maeda, H.; Wu, J.; Sawa, T.; Matsumura, Y.; Hori, K.; J. Controlled Release 2000, 65, 271.

18. Rico, S. R. A.; Abbasi, A. Z.; Ribeiro, G.; Ahmed, T.; Wu, X. Y.; Silva, D. O.; Nanoscale 2017, 9, 10701.

19. Alves, S. R.; Wu, X. Y.; Colquhoun, A.; Silva, D. O.; J. Inorg. Biochem. 2020, 205, 110984.

20. Kim, J.; Pramanick, S.; Lee, D.; Par, H.; Kim, W. J.; Biomater. Sci. 2015, 3, 1002.

21. Zeng, L.; Gupta, P.; Chen, Y.; Wang, E.; Ji, L.; Chao, H.; Chen, Z.; Chem. Soc. Rev. 2017, 46, 5771.

22. Thangavel, P.; Viswanath, B.; Kim, S.; Int. J. Nanomed. 2017, 12, 2749.

23. Villemin, E.; Ong, Y. C.; Thomas, C. M.; Gasser, G.; Nat. Rev. Chem. 2019, 3, 261. 
24. Petruk, G.; Monti, D. M.; Ferraro, G.; Pica, A.; D’Elia, L.; Pane, F.; Amoresano, A.; Furrer, J.; Kowalski, K.; Merlino, A.; ChemMedChem 2019, 14, 594.

25. Fischer, B.; Heffeter, P.; Kryeziu, K.; Gille, L.; Meier, S. M.; Berger, W.; Kowol, C. R.; Keppler, B. K.; Dalton Trans. 2014, 43, 1096.

26. Blunden, B. M.; Rawal, A.; Lu, H.; Stenzel, M. H.; Macromolecules 2014, 47, 1646.

27. Dizaj, S. M.; Vazifehasl, Zh.; Salatin, S.; Adibkia, Kh.; Javadzadeh, Y.; Res. Pharm. Sci. 2015, 10, 95.

28. Ribeiro, G.; Benadiba, M.; Colquhoun, A.; Silva, D. O.; Polyhedron 2008, 27, 1131

29. Benadiba, M.; Santos, R. R. P.; Silva, D. O.; Colquhoun, A.; J. Inorg. Biochem. 2010, 104, 928.

30. Ribeiro, G.; Benadiba, M.; Silva, D. O.; Colquhoun, A.; Cell Biochem. Funct. 2010, 28, 15.

31. Santos, R. L. S. R.; Bergamo, A.; Sava, G.; Silva, D. O.; Polyhedron 2012, 42, 175.

32. Benadiba, M.; Costa, I. M.; Santos, R. L. S. R.; Serachi, F. O.; Silva, D. O.; Colquhoun, A.; J. Biol. Inorg. Chem. 2014, 19, 1025.

33. Miyake, J. A.; Benadiba, M.; Ribeiro, G.; Silva, D. O.; Colquhoun, A.; Anticancer Res. 2014, 34, 1901.
34. Hanif-Ur-Rehman; Freitas, T. E.; Gomes, R. N.; Colquhoun, A.; Silva, D. O.; J. Inorg. Biochem. 2016, 165, 181.

35. Santos, R. L. S. R.; van Eldik, R.; Silva, D. O.; Inorg. Chem. 2012, 51, 6615 .

36. Santos, R. L. S. R.; van Eldik, R.; Silva, D. O.; Dalton Trans. 2013, 42, 16796.

37. Santos, R. L. S. R.; Sanches, R. N. F.; Silva, D. O.; J. Coord. Chem. 2015, 68, 3209.

38. Messori, L.; Marzo, T.; Sanches, R. N. F.; Hanif-Ur-Rehman; Silva, D. O.; Merlino, A.; Angew. Chem., Int. Ed. 2014, 53, 6172.

39. Angaridis, P. In Multiple Bonds between Metal Atoms, $3^{\text {rd }}$ ed.; Cotton, F. A.; Murillo, C. A.; Walton, R. A., eds.; Springer Science and Busines Media Inc.: New York, 2005, p. 377.

40. Aquino, M. A. S.; Coord. Chem. Rev. 1988, 170, 141.

41. Bilati, U.; Allémann, E.; Doelker, E.; Eur. J. Pharm. Sci. 2005, 24, 67.

42. Riccardi, C.; Musumeci, D.; Trifuoggi, M.; Irace, C.; Paduano, L.; Montesarchio, D.; Pharmaceuticals 2019, 12, 146.

Submitted: February 4, 2020

Published online: May 18, 2020 